in official memoranda, and undertook extensive tours throughout England and Wales to impress the need for infant welfare on local educational authorities. At this time also Sir Arthur Newsholme's important reports influenced the Local Government Board to stimulate local authorities by State grants to provide a maternity and child-welfare service. The establishment of the Ministry of Health in 1919 with Dr. Campbell as the senior medical officer of the Maternity and Child Welfare Branch and similar rank in the Board of Education integrated medical administrative work in Whitehall on this subject.

At the Ministry of Health, Dame Janet and her able staff did excellent work. In addition to serving on a number of important Government committees, including the War Cabinet Committee on Women in Industry, the Committee on the Training of Midwives and the Committee on Maternal Mortality, she served on the Health Committee of the League of Nations and rendered valuable service to international maternity and child welfare work during 1930-36. She also wrote a number of searching reports on her special subject. These led to many important reforms which have helped to reduce maternal and infant mortality in recent years.

She was created a D.B.E. in 1924, received the honorary degree of doctor of hygiene of the University of Durham, and was a justice of the peace for Surrey and for Gloucestershire. On her retirement in 1934 she married Mr. Michael Heseltine, registrar of the General Medical Council; he died in 1952.

Dame Janet was tall and good-looking. A somewhat reserved manner cloaked her enthusiasm for the cause to which she devoted her life, but those who knew her and worked with her fully appreciated her great qualities. ARThur S. MacNalty

\section{Mr. A. de C. Sowerby}

Arthur de Carle Sowerby, who died in Washington, D.C., on August 16, was a member of that branch of the Sowerby family which included such well-known scientific figures as James Sowerby, the artist-naturalist of "English Botany" fame, and James de Carle Sowerby, who was first secretary of the Royal Botanic Gardens in Regent's Park, London.

Arthur de Carle Sowerby was born in 1885 at Taiyuan-Fu, Shansi, and during an adventurous career accomplished much to promote the study of China's natural history, both as an explorer and as a writer. Among the expeditions in which Sowerby took a prominent part was a trip to Shansi and the Ordos Desert in 1908, with Mr. Malcolm Anderson, who was collecting mammals for the British Museum under the auspices of the Duke of Bedford's Zoological Exploration of Eastern Asia. This venture was successful and resulted in many new forms of mammals being collected and sent to the British Museum, where they were duly described and reported upon. In 1909 Sowerby, in the capacity of naturalist, accompanied Mr. Robert Sterling Clark to north-western China, and thereafter, up to the end of 1917, he travelled in northern and eastern China, Inner Mongolia and Manchuria, collecting on behalf of the United States National Museum in Washington.

These journeys and their scientific results have been described by Sowerby in the travel-books which he published between 1912 and 1930. Thus, the Clark Expedition was described in "Through Shên-
Kan" (1912), written jointly with R. S. Clark. Perhaps the most important of these works by Sowerby is his "Naturalist in Manchuria,", published in five volumes between 1922 and 1930, containing an account of the vertebrate and invertebrate fauna of the region.

In 1911 he organized and led the Shensi Relief Expedition during the Chinese Revolution, a mission which was succossfully carried out after a journey of 2,000 miles.

After the First World War, Sowerby returned to China and busied himself with further explorations and collecting work in Fukien Province, and later made a biological survey of the country accessible from Shanghai.

In 1923 he founded the China Journal of Science and Arts, of which he was the editor for fifteen years. This valuable journal was a noteworthy contribution to cultural activities in Shanghai. It continued until 1941 and contains much valuable material on the natural history and antiquities of China, "handled", as Sowerby himself has expressed it, "in a more or less popular, but at the same time thoroughly authentic way".

He was also associated with the Shanghai Museum of the Royal Asiatic Society, becoming later honorary director of the Museum and president of the North China Branch of the Society from 1936 until 1940. $\mathrm{He}$ also helped to found the China Society of Science and Art, and the Numismatic Society of China, of which he was president. He was also president of the Naturalists' Club of Shanghai, founded in 1935, and to which he delivered the first presidential address, taking as his subject the "Progress of Biological Work in China".

$\mathrm{He}_{e}$ contributed many articles to scientific journals, newspapers, and to the China Journal. During 1943-49, the Heude Museum of Shanghai published several of his papers, the most considerable of which were probably his account of the birds of the Shanghai area, and a review of the mammals of the Japanese Islands, both of which were published in 1943.

Sowerby was interned by the Japanese in 1944, and when released, made his way via England to the United States, where he finally took up residence, in Washington, D.C. At the time of his death this genial and many-sided man was engaged upon a history of the Sowerby family, which he entitled "The Sowerby Saga". This was written in collaboration with his wife and $a_{0}$ cousin, and the first three mimeographed parts appeared in 1952. In the first two parts of this work the origin and early and middle history of the Sowerby family are discussed, while the third part begins the story of Arthur de Carle's own life and activities down to 1912. It is to be hoped that it will be found possible to publish a further instalment of this vivid and interesting narrative.

A. C. Townsend

\section{Mr. Talbot Peel}

Mr. TALbot PeEL, whose death at the age of eighty-two occurred at Cambridge on September 17, had been a Fellow of Magdalene College for some forty-five years. Born on July 4, 1872, he was the son of Norris Peel, of Stonegarth, Huddersfield.

From Huddersfield College he proceeded to Magdalene College, where he was fifth Wrangler in the Mathematical Tripos (1893) and placed in the first class of the Mechanical Sciences Tripos (1894). He then went to C. A. Parsons, Ltd., Newcastle upon 
Tyne, for a period of training in practical engineering, in particular on steam turbines, which were then in the early stages of development. $\mathrm{He}$ returned to Cambridge to take up a teaching post at the Leys School. Later he joined the staff of the Engineering Department of the University and, in 1909, was elected a Fellow of Magdalene College. Here he was director of studies in mechanical sciences and, for many years, bursar and steward, offices which he filled with enthusiasm and distinction. $\mathrm{He}$ was appointed to the Hopkinson lectureship in applied thermodynamics in 1930 and occupied that post until he reached the retiring age.
Peel's interests were by no means confined to the academic sphere; for example, he represented the University on the Borough Council for eleven years, was a member of the General Committee of Addenbrooke's Hospital and also served on the Finance Committee of the Evelyn Nursing Home.

His long connexion with the University and City of Cambridge was marked by never-failing courtesy and gentleness, characteristics which endeared him to all those with whom he came into contact. $\mathrm{He}$ is survived by his wife Elsie, née Penman, whom he married in 1914, and by their daughter Elizabeth.

J. Trevor Spittle

\section{NEWS and VIEWS}

\section{Atomic Energy for Peaceful Purposes}

ON September 6, President Eisenhower announced that agreement had been reached between the United States and six other nations to establish an international agency which would foster the growth and spread of the new atomic technology for peaceful purposes. Atomic materials would be set aside for projects sponsored by the agency, and when arrangements were complete the United States would establish a reactor school to train representatives of friendly nations in the skills needed for their own atomic purposes. The United States was about to negotiate with the Belgian Government on the building of an atomic power reactor in that country, and discussions with Canada and with other countries that intended to build their own research reactor units would follow. President Eisenhower expressed the hope that no nation would stand aloof from such co-operation. Since then, at the General Assembly of the United Nations, Mr. Leslie Pearson, the Canadian Foreign Minister, on September 23 said that Canada believed that even without Soviet participation an international atomic agency along the lines proposed by President Eisenhower could usefully be formed, and Mr. Dulles, the American Secretary of State, affirmed the determination of the United States to implement the proposals originally made by President Eisenhower on December 8, 1953. Mr. Dulles indicated that it was now proposed to create an international agency the initial membership of which included nations from all regions of the world; to call an international conference next spring, under the auspices of the United Nations, to consider the whole subject; to open next year in the United States a reactor-training school where students from abroad might learn the working principles of atomic energy with specific reference to its peace-time uses; and to invite medical and surgical experts from abroad to participate in the work of American cancer hospitals, in which atomic energy techniques were among the most hopeful approaches to the control of this disease. No nation would be excluded from participation in this venture. On September 26, the State Department published without comment twelve notes, memoranda and aides-mémoire, exchanged in Washington and during the Berlin Conference in February between the United States and the Soviet Union, giving details of President Eisenhower's proposals of December 8, and showing how the two countries failed to reach agreement, but were still willing to continue the negotiations.

\section{Journal of Nuclear Energy}

RESEARCH work in the field of nuclear energy is now being carried out in many national establishments throughout Europe. Much of this work is of interest to nuclear physicists in general, but has perhaps tended to remain unpublished because of its specialized technical nature. The appearance of the quarterly Journal of Nuclear Energy, edited by J. V. Dunworth, J. Guéron and G. Randers, will therefore be welcomed not only by members of the official organizations, among whom it will circulate technical information, but also by many others with an interest in the experimental possibilities of nuclear reactors (London: Pergamon Press. Single issues 25s.; annual subscription, 4 issues, 90s.). The articles in the first number of the new Journal justify the claim of the publishers that it will "provide an outlet for papers dealing with the scientific, engineering, biological and economic aspects of nuclear energy". All these are represented, and at least two of the articles, those by C. A. Rennie on "Economic Power" from Fast Breeder Reactors" and by J. F. Loutit on "Protection against Ionising Radiation", are of wide general interest. Although most of the papers in the first number come from Harwell, contributions from Kjeller (Norway) and Saclay (France) are included, and all are of a high scientific standard. The layout of the new Journal is attractive, and the printing and illustrations are of good quality; it deserves a wide circulation.

\section{Communications and Electronics}

A NEw British technical journal was launched in September under the title Communications and Electronics; it is intended to present monthly a review of the new practical applications of communications and electronic techniques, which are rapidly becoming one of the major industries in Great Britain. The purpose of this new journal is well illustrated in an introductory article in the first issue, by Sir Walter Puckey, who states that "the aim is to show other specialists what telecommunication and electronic systems can do, rather than how they work". Bearing in mind that these techniques are nowadays applied over a very wide range of industry and commerce, as well as to medicine and almost every field of research, this new publication may well fill a long-felt noed. The scope is illustrated by the series of articles in the first issue. These deal on the radio side with such subjects as navigational aids in civil aviation, telecommunications at London 